\title{
Longitudinal study on the effects of intramammary infection with non-aureus staphylococci on udder health and milk production in dairy heifers
}

\author{
D. Valckenier, ${ }^{1} \odot$ S. Piepers, ${ }^{1} \odot$ Y. H. Schukken, ${ }^{2,3,4} \odot$ A. De Visscher,,${ }^{1,5}$ F. Boyen, ${ }^{6} \odot$ F. Haesebrouck, ${ }^{6} \oplus$ \\ and S. De Vliegher ${ }^{1 *}$ (1) \\ ${ }^{1}$ M-team and Mastitis and Milk Quality Research Unit, Department of Reproduction, Obstetrics and Herd Health, Faculty of Veterinary Medicine, \\ Ghent University, B-9820 Merelbeke, Belgium \\ ${ }^{2}$ GD Animal Health, PO Box 9, 7400 AA Deventer, the Netherlands \\ ${ }^{3}$ Department of Animal Sciences, Wageningen University, 6708 PB Wageningen, the Netherlands \\ ${ }^{4}$ Department of Population Health Sciences, Utrecht University, $3584 \mathrm{CL}$, Utrecht, the Netherlands \\ ${ }^{5}$ Flanders Research Institute for Agriculture, Fisheries, and Food (ILVO), Technology and Food Science, Agricultural Engineering, \\ B-9820 Merelbeke, Belgium \\ ${ }^{6}$ Department of Pathology, Bacteriology, and Avian Diseases, Faculty of Veterinary Medicine, Ghent University, B-9820 Merelbeke, Belgium
}

\begin{abstract}
We conducted a longitudinal study to evaluate the effect of non-aureus staphylococci (NAS) causing subclinical intramammary infections (IMI) on quarter milk somatic cell count (qSCC) and quarter milk yield (qMY). In total, 324 quarters of 82 Holstein Friesian heifers were followed from calving to $130 \mathrm{~d}$ in milk (DIM) and were sampled 10 times each at 14-d intervals. The IMI status of each quarter was determined based on bacterial culture results at the current and previous or next sampling day, or both. The qSCC was determined on each sampling day and the average qMY on sampling day was available through stored daily milk weight data in the management program of the automatic milking system. A transient IMI (tIMI) was defined as a case where a specific pathogen was isolated from a quarter on only one sampling day and not on the previous or next sampling day. When the same bacterial strain, as defined by random amplification of polymorphic DNA-PCR, was isolated from the same quarter on multiple sampling days, it was defined as a persistent IMI (pIMI) status on those sampling days; a pIMI episode was defined as the combination of multiple consecutive pIMI statuses with the same bacterial strain on different sampling days. During this study, 142 subclinical IMI with NAS occurred in 116 different quarters from 64 animals, yielding in total 304 NAS
\end{abstract}

Received April 9, 2020.

Accepted September 1, 2020.

*Corresponding author: Sarne.Devliegher@UGent.be isolates belonging to 17 different species. The prevalence of NAS was highest in the first 4 DIM. Overall, the predominant species was Staphylococcus chromogenes ( $52 \%$ of the isolates), followed by $S$. epidermidis (9.2\%), S. xylosus (8.2\%), and S. equorum (5.9\%). Staphylococcus chromogenes was the only species for which an effect on qSCC and qMY could be analyzed separately; the other NAS species were considered as a group because of their low prevalence. Eighteen out of 40 IMI $(45 \%)$ caused by S. chromogenes persisted over at least 2 sampling days, whereas only 10 of 102 (9.8\%) IMI caused by other NAS species persisted for at least 2 sampling days. The average duration of pIMI episodes was $110.4 \mathrm{~d}$ for $S$. chromogenes and $70 \mathrm{~d}$ for the other NAS species. Remarkably, 17 of the 18 pIMI episodes with $S$. chromogenes started within the first 18 DIM. The qSCC was highest in quarters having a pIMI with a major pathogen, followed by quarters having a pIMI with $S$. chromogenes, and a pIMI with other NAS. Transient IMI with other NAS or with a major pathogen caused a small but significantly higher qSCC, whereas the qSCC in quarters having a tIMI with $S$. chromogenes was not statistically different compared with noninfected quarters. No significant differences in qMY were observed between quarters having a pIMI or tIMI with $S$. chromogenes or with the other NAS species compared with noninfected quarters, despite the higher qSCC. Quarters having a pIMI with major pathogens showed significantly lower daily milk production. Surprisingly, quarters that cured from an IMI with $S$. chromogenes had a significantly lower qMY than noninfected quarters.

Key words: non-aureus staphylococci, species-specific intramammary infection, quarter milk yield, quarter somatic cell count 


\section{INTRODUCTION}

Mastitis is the most important disease in the dairy sector worldwide and one of the most frequent reasons for antimicrobial therapy in dairy herds (Brunton et al., 2012; Stevens et al., 2016). In the past few decades, non-aureus staphylococci (NAS) have become the most common pathogen isolated from subclinical mastitis cases in dairy cows in many regions (Pitkälä et al., 2004; Piepers et al., 2007; Pyörälä and Taponen, 2009; Reyher et al., 2011). This group of staphylococci is present in almost every dairy herd. They were recovered from 299 out of 300 bulk milk samples from 100 Belgian dairy herds (De Visscher et al., 2017) and 100\% of all 4,258 Danish dairy herds (Katholm et al., 2012). Risk factors at the herd, cow, and quarter level have been identified for multiple species (Piessens et al., 2011; Bexiga et al., 2014; De Visscher et al., 2016). Heifers are more prone to NAS IMI than are multiparous cows (Matthews et al., 1992; Tenhagen et al., 2006; Sampimon et al., 2009; De Vliegher et al., 2012).

Regarding the impact of NAS on udder health; that is, SCC in case of subclinical mastitis, most studies consider NAS as minor pathogens causing only a moderate increase in SCC or causing mild clinical mastitis (CM) cases (Schukken et al., 2009; Fry et al., 2014; Tomazi et al., 2015; Valckenier et al., 2019). However, more disagreement exists with regard to potential species differences in their effect on udder health. Some studies found no significant differences in quarter milk SCC (qSCC) between different NAS species (Hogan et al., 1987; Bexiga et al., 2014), whereas others noted that important species differences exist (Supré et al., 2011; Fry et al., 2014). Moreover, in our previous study, we concluded that IMI with $S$. chromogenes starting in the first 18 DIM resulted in a significantly higher qSCC during the first 130 DIM, whereas IMI with the group of other NAS species had no effect on qSCC (Valckenier et al., 2020). Some NAS species, such as Staphylococcus chromogenes, S. simulans, and S. xylosus, are called species "more relevant for udder health" as they are able to increase the qSCC to a level comparable to that of $S$. aureus (Supré et al., 2011), as substantiated by Fry et al. (2014). Heifers are at greater risk for infections with the "more relevant" NAS species compared with multiparous cows (De Visscher et al., 2015), especially at the beginning of their lactation (Taponen et al., 2007). Similar to differences observed for the effect on SCC, species-specific differences in persistence capacity were reported as well (Supré et al., 2011; Mørk et al., 2012; Nyman et al., 2018).

The effect of NAS infections on milk yield (MY) is even more debated, although most recent research con- siders NAS minor pathogens with little to no effect on the quarter MY (qMY; Tomazi et al., 2015; Heikkilä et al., 2018; Valckenier et al., 2019, 2020). If IMI with all of the different NAS species have a negative or no effect on MY, the focus should remain on prevention of infection with these pathogens because NAS IMI lead to an elevated SCC and have been previously identified as a risk factor for developing IMI with $S$. aureus (Reyher et al., 2012a). On the other hand, if certain NAS species have a positive effect on MY or if the protective effects of NAS IMI against infections with major pathogens demonstrated in challenge studies hold true in larger observational studies (Reyher et al., 2012b), they could be interesting in the development of new concepts or strategies in the dairy sector. A downside of most previous studies scrutinizing the association between NAS IMI and MY is that the IMI status of the cow was an aggregate of the IMI statuses of the quarters, and that MY was also measured at the cow level. This has led to a variety of conclusions, with some classifying NAS as pathogens with a potential negative effect on MY (Timms and Schultz, 1987; Gröhn et al., 2004; Taponen et al., 2006), some reporting the absence of association with MY (Compton et al., 2007; Paradis et al., 2010; Pearson et al., 2013), and others finding a higher MY in infected animals than in noninfected animals (Schukken et al., 2009; Piepers et al., 2013). However, to our knowledge, no research has been performed so far in which both quarter IMI status and quarter MY have been observed simultaneously in a longitudinal study.

The question remains whether IMI with the "more relevant" NAS species, in particular $S$. chromogenes, affect qSCC and qMY. This longitudinal study therefore aimed to evaluate the effect of subclinical NAS IMI during the first 130 DIM on qSCC and qMY in heifers (i.e., animals in first lactation) in 3 dairy herds milking with automated milking systems (AMS).

\section{MATERIALS AND METHODS}

\section{Herds and Animals}

Data and samples were collected during a longitudinal study conducted from August 2013 until the end of October 2014, as described in Valckenier et al. (2019). Briefly, the study included 3 Belgian commercial dairy herds, all located in the province of West Flanders and equipped with an AMS. None of the 3 herds treated their end-term heifers with antimicrobials before calving, nor did they participate in the local dairy herd improvement program.

During the sampling period, 82 heifers calved, and all were included in the study because no further inclusion 
or exclusion criteria were applied at the herd or heifer level. When a heifer was sold, culled, or died within the first 4 mo of lactation, it was not replaced by another animal. Nonfunctional quarters or quarters with $\mathrm{CM}$ before or at the first sampling were excluded because the aim of this study was to investigate the effects of IMI with NAS causing subclinical mastitis. For this reason, 2 quarters with $\mathrm{CM}$ and 2 nonfunctional quarters were excluded. In addition, 2 heifers from herd 3 were culled after a severe case of CM between 57 and 74 DIM. One quarter from a heifer in herd 1 was immediately dried off after a CM case occurring between 85 and 102 DIM. Two heifers (herds 2 and 3 ) were sold between 85 and 102 DIM. The left hind quarter from a heifer in herd 3 was dried off at 85 DIM because of a teat-end injury. All quarter samples taken before these animals were culled or dried off were included in the analysis.

\section{Study Design, qSCC, and qMY}

Every included quarter from all heifers was sampled by the first author between 1 and 4 DIM (referred to as sampling $d 1$ throughout the paper) and followed until 127 to 130 DIM by collecting milk samples every $14 \mathrm{~d}$ another 9 consecutive times after the first sampling, resulting in 10 repeated samplings per quarter with a 14-d interval (referred to as sampling days). Quarter milk samples were collected aseptically according to the guidelines of the National Mastitis Council (Hogan et al., 1999) and transported in a cooled box to the laboratory of the Mastitis and Milk Quality Research Unit (Ghent University, Merelbeke, Belgium) immediately after sampling for further processing. The heifers were either separated in the selection unit of the AMS if they had been milked in the last few hours before sampling or were searched for in the barn. All heifers were restrained in head lockers at the moment of sampling. The time interval between the last milking before the sampling and the sampling itself varied because all animals were milked voluntarily by the AMS.

The qSCC of each sample was measured using a DCC Direct Cell Counter (DeLaval International AB, Tumba, Sweden). Quarter milk production per milking was available through the herd management software of the AMS (DelPro, DeLaval International AB). The average daily qMY at the first sampling day (1-4 DIM) was calculated by summing the qMY of all milkings from calving up to d 7 after the sampling and dividing by the number of days. Subsequently, the qMY was also available for an additional 9 consecutive 14-d periods (sampling days) by calculating the average daily qMY during each of these 14-d periods.

\section{Microbiology}

All quarter milk samples taken at each sampling day were used for bacteriological culturing to determine the IMI status of each quarter. Standard bacteriological culture was done by spreading a 0.01-mL loop of milk on 5\% sheep blood agar and MacConkey agar no. 3 (Thermo Fisher Diagnostics N.V., Groot-Bijgaarden, Belgium), as described elsewhere (Valckenier et al., 2019). All plates were incubated aerobically at $37^{\circ} \mathrm{C}$ and phenotypically examined after $24 \mathrm{~h}$ and again after $48 \mathrm{~h}$; identification of bacteria was done using recommended phenotype-based bacteriological procedures (Hogan et al., 1999). Milk samples were considered culture-positive if one or more colonies were observed ( $\geq 100 \mathrm{cfu} / \mathrm{mL}$; Dohoo et al., 2011b). Samples yielding 3 or more different colony types were considered to be contaminated. Staphylococcus aureus, esculin-positive and esculin-negative gram-positive cocci, Trueperella pyogenes, Escherichia coli, Klebsiella spp., and other gram-negative bacteria were regarded as major pathogens. All bacteria not belonging to the group of NAS or to one of the abovementioned major pathogens were considered "other" bacteria. A sample yielding a major pathogen and NAS or other bacteria was classified as culture-positive for the major pathogen, whereas a sample yielding 2 different major pathogens or 2 different minor pathogens was considered as culture-positive for the pathogen with the highest count $(\mathrm{cfu} / \mathrm{mL}$; Valckenier et al., 2019, 2020).

\section{NAS Species Identification and Strain-Typing}

All isolates phenotypically identified as NAS during the trial were stored in Microbank vials (Pro-Lab diagnostics, Richmond Hill, ON, Canada) at $-80^{\circ} \mathrm{C}$ until the end of the sampling period. These isolates were identified at the species level using transfer RNA intergenic spacer (tDNA)-PCR or, if no identification was obtained, sequencing of the $16 S$ rRNA or rpoB gene as described by Supré et al. (2009), or MALDI-TOF MS (Cameron et al., 2017).

Random amplification of polymorphic DNA (RAPD)-PCR was used for strain-typing if the same NAS species was isolated $\geq 2$ times on different sampling days from the same quarter (Figure 1). The RAPD-PCR was performed as described by Piessens et al. (2012) with some modifications. The amplified DNA fragments were separated on $1.5 \%$ (wt/vol) agarose gels, previously stained with ethidium bromide $(10 \mathrm{mg} / \mathrm{mL}$; Sigma Aldrich, St. Louis, MO), at 120 $\mathrm{V}$ for $75 \mathrm{~min}$. Representative isolates from the same 


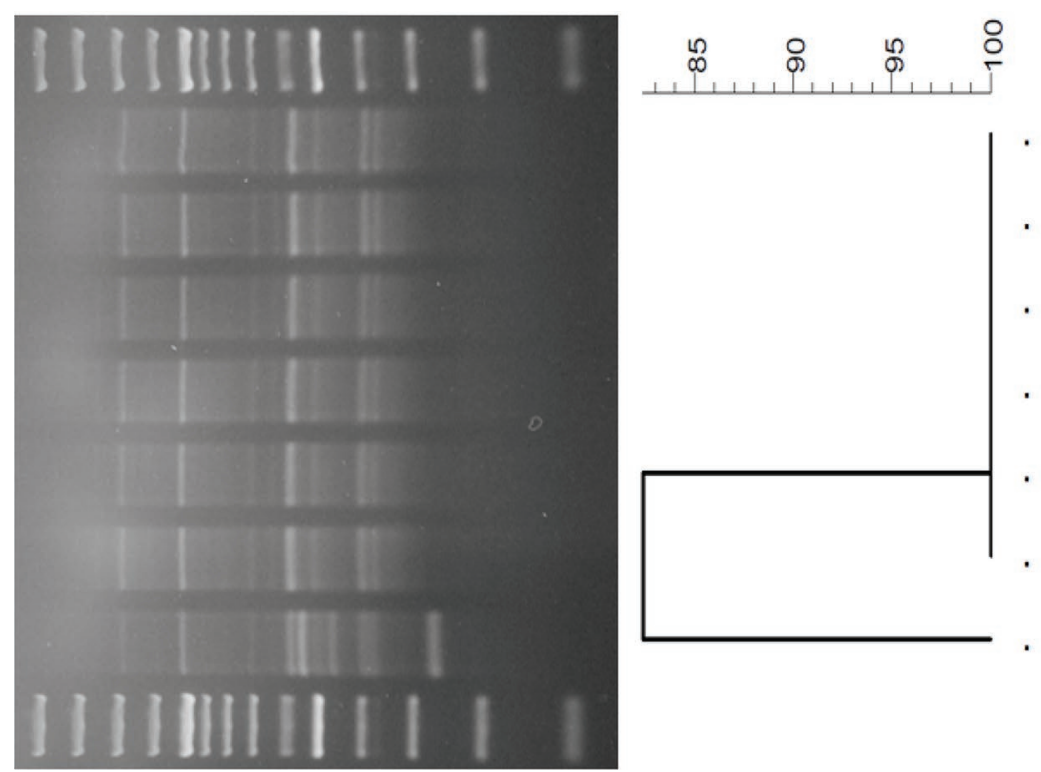

\begin{tabular}{|l|l|l|}
\hline NAS isolate & RAPD type & $\begin{array}{l}\text { Quarter ID - } \\
\text { Sampling day }\end{array}$ \\
\hline S. chromogenes & A & $28-$ SD7 \\
\hline S. chromogenes & A & $28-$ SD6 \\
\hline S. chromogenes & A & $28-$ SD5 \\
\hline S. chromogenes & A & $28-$ SD4 \\
\hline S. chromogenes & A & $28-$ SD3 \\
\hline S. chromogenes & A & $28-$ SD2 \\
\hline S. chromogenes & B & $28-$ SD1 \\
\hline
\end{tabular}

Figure 1. Random amplification of polymorphic DNA (RAPD)-PCR fingerprints and dendrogram of NAS species isolated $\geq 2$ times from the same quarter (example of 1 quarter from which Staphylococcus chromogenes was isolated on 8 sampling days). Isolates from the same quarter were analyzed in the same PCR run and were run side-by-side on the same gel. Isolates belonging to the same RAPD type were assigned an arbitrary letter based on clustering. A quarter was considered persistently infected with the same NAS strain from the first to the last sampling day (SD) on which this NAS strain belonging to the same RAPD type was isolated.

quarter were analyzed in the same PCR run and were run side-by-side on the gel. Gels were photographed by UV transillumination. The images were inspected visually, imported into BioNumerics version 7.6.3 (Applied Maths, Sint-Martens-Latem, Belgium), and analyzed following Adkins et al. (2017) using the Dice similarity coefficient and the unweighted pair group method with arithmetic mean (UPGMA). The optimization and position tolerance were set at 0.5 and $1.0 \%$, respectively, for different isolates to be considered the same strain type. If the NAS isolates from the same quarter belonged to the same RAPD type, the quarter was considered persistently infected with the same NAS strain from the first until the last sampling day on which this NAS strain belonging to the same RAPD type was isolated. A quarter with a culture-negative sampling between 2 culture-positive samplings with the same RAPD type was still considered as having a pIMI on the culturenegative sampling day.

\section{Sampling Day IMI Status}

The sampling day IMI status was defined by combining culture results of the previous, current, and next sampling day (e.g., to determine the IMI status on sampling d 5, the culture results at sampling d 4, 5, and 6 were used). A quarter was defined as noninfected on the current sampling day if the milk samples were culture-negative on the previous and current sampling days. A quarter was defined as having a transient IMI (tIMI) with a specific pathogen on the current sampling day if the milk sample was culture-positive for a specific pathogen on the current sampling day and the same pathogen was not isolated on the previous and next sampling day. If a quarter was considered infected with the same pathogen on at least 2 sampling days, this quarter was defined as having a persistent IMI (pIMI) on those sampling days. Quarters were only considered to have a pIMI with a certain NAS species if the same NAS species isolated on multiple sampling days belonged to the same RAPD type. A "pIMI episode" is the combination of multiple consecutive pIMI statuses with the same pathogen on different sampling days (i.e., 1 pIMI episode consists of at least 2 and up to 10 consecutive pIMI statuses with the same pathogen in our study). A quarter was defined as having a cured IMI (cIMI) on the current sampling day if it was infected with a specific pathogen on the previous sampling day and the milk sample was culture-negative on the current sampling day and not infected with the same bacterial strain on the next sampling day.

The IMI status on the first sampling day was determined by combining the culture results from only the first and second sampling days. A quarter was defined to be noninfected on the first sampling day if the milk sample was culture-negative for any pathogen. When the milk sample on the first sampling day was culturepositive for a specific pathogen but the same pathogen 
could not be isolated on the second sampling day, the quarter was determined as having a tIMI on the first sampling day. When a quarter was infected with the same pathogen on both the first and second sampling days, the quarter was considered as having a pIMI on both those sampling days.

The IMI status on the last sampling day was determined using the culture results on sampling d 9 and 10 . When a quarter was infected with the same pathogen on sampling d 9 and 10 or was culture-negative on both sampling days, the quarter was considered as having a pIMI or being noninfected, respectively, on sampling d 10. Statuses of samples that were culture-negative on sampling d 9 and culture-positive on sampling d 10 were defined as missing because we could not determine whether it was a tIMI or a pIMI (right-censoring). A cIMI on sampling d 10 was defined as a quarter being infected with a certain pathogen on sampling d 9 but yielding a culture-negative milk sample on sampling $d$ 10.

The IMI status of sampling days for which the NAS isolate could not be identified to the species level, or when the milk sample was contaminated, or was culture-positive for a pathogen belonging to the group of "other" bacteria, or could not be classified into a certain IMI status according to the above definitions was categorized as "undefined."

\section{Start and End Point of IMI and Duration of a pIMI Episode}

The determination of the start and end point of an IMI episode was adapted from Supré et al. (2011). When a quarter was infected on the first sampling day, the start point of this IMI episode was defined as the first DIM. When a quarter became infected thereafter, the infection was assumed to have started half-way between the previous and current sampling day. The endpoint of infection was considered to be the midpoint between the sampling with IMI and the next sampling without IMI. When the quarter was infected at the end of the follow-up period, an extra $7 \mathrm{~d}$ was added to the calculation [i.e., the average number of days between 2 samplings, divided by 2].

\section{Statistical Analyses}

All data were entered in an electronic spreadsheet program (Excel 2016, Microsoft Corp., Redmond, WA) and were checked for unlikely values.

Common Features of the Statistical Models. The associations between the quarter-level sampling day IMI (qIMI; categorical predictor variable of main interest) status and sampling day qSCC and sampling day qMY (outcome variables) throughout the first 4 mo of lactation were determined fitting 2 separate linear mixed models. Herd (forced into the model as fixed effect), heifer (random effect), and quarter (random effect) were included in the models to correct for potential clustering of heifers within herds, for clustering of quarters within heifer, and for clustering of observations (10 repeated samplings) within quarters, respectively. As the number of observations was too small for the species other than $S$. chromogenes, these were included as a group (named "NAS other than $S$. chromogenes") in the statistical analyses. By doing so, the qIMI status at sampling day had 11 levels: noninfected; tIMI, pIMI, and cIMI with S. chromogenes; tIMI, pIMI, and cIMI with NAS other than S. chromogenes; tIMI, pIMI, and cIMI with a major pathogen; and quarters with an undefined IMI status on a certain sampling day. A natural logarithmic transformation of the qSCC (qLnSCC) was performed to obtain a normal distribution. The qSCC at sampling day was included as explanatory variable in the qMY model. The models included quarter position (2 levels: front vs. hind) as categorical predictor variable. The model with qSCC as outcome variable included sampling day (10 levels: 1 to 10) as categorical predictor variable, whereas the 4 parametric lactation curve function by Ali and Schaeffer (AS; Ali and Schaeffer, 1987) was used for fitting the lactation MY curve in the qMY model.

The linear mixed models were fit in SAS (PROC MIXED; version 9.4; SAS Institute Inc., Cary, NC). The goodness-of-fit measures included $-2 \times \log -$ likelihood, the Akaike information criterion, and the Bayesian information criterion. Residuals were evaluated graphically and plotted against the predicted values. A Bonferroni's correction was used to correct for multiple comparisons. Significance was assessed at $P \leq$ 0.05 . Nonsignificant variables $(P>0.05)$ were omitted using a backward stepwise approach. In all linear mixed models, a first-order autoregressive correlation structure was used to account for the clustering of repeated sampling days within a quarter.

Effect of tIMI, pIMI, and cIMI on $q S C C$. The initial linear mixed model with qSCC as outcome variable (SCC model; Eq. [1]) was

$$
\begin{aligned}
\mathrm{qLnSCC}_{i j k l}=\beta_{0} & +\beta_{1} \mathrm{qIMI}_{i j k l}+\beta_{2} \text { quarter position }_{j k l} \\
+\beta_{3} \operatorname{herd}_{l} & +\beta_{4} \text { sampling day }_{i j k l}+\mu_{\text {Heifer } k l(j)} \\
& +\mu_{\text {Quarter } j k l(i)}+\mathrm{e}_{i j k l},
\end{aligned}
$$

where $\mathrm{qLnSCC}_{i j k l}$ is the natural logarithm of $\mathrm{SCC}$ for the $i$ th sample $(i=1-10)$ of the $j$ th quarter $(j=1-4)$ of the $k$ th heifer $(k=1-82)$ from the $l$ th herd $(l=1-3) ; \beta_{0}$ is the intercept (overall mean); $\beta_{1}$ to $\beta_{4}$ are the regression 
coefficients of the fixed effects: quarter-level IMI status on sampling day, quarter position, herd, and sampling day, respectively; $\mu_{\text {Heifer } k l(j)}$ is the random effect of the heifer $k$ from herd $l$ to correct for clustering of quarters within heifer; $\mu_{\text {Quarter } j k l(i)}$ is the random effect to correct for within-quarter correlation of subsequent biweekly sampling days $i$ (repeated statement) for quarter $j$ of heifer $k$ from herd $l$; and $\mathrm{e}_{i j k l}$ is the random error term.

Effect of tIMI, pIMI, and cIMI on $q M Y$. The initial linear mixed model with daily qMY as outcome variable (MY model; Eq. [2]) was

$$
\begin{gathered}
\mathrm{qMY}_{i j k l}=\beta_{0}+\beta_{1} \mathrm{qIMI}_{i j k l}+\beta_{2} \text { quarter position }{ }_{j k l} \\
+\beta_{3} \operatorname{herd}_{l}+\beta_{4} \text { AS term } 1_{i j k l}+\beta_{5} \text { AS term } 2_{i j k l} \\
+\beta_{6} \text { AS term } 3_{i j k l}+\beta_{7} \text { AS term } 4_{i j k l}+\beta_{8} \mathrm{qLnSCC}_{i j k l} \\
+\mu_{\text {Heifer } k l(j)}+\mu_{\text {Quarter } j k l(i)}+\mathrm{e}_{i j k l},
\end{gathered}
$$

where qMY is the quarter milk yield for the $i$ th sample $(i=1-10)$ of the $j$ th quarter $(j=1-4)$ of the $k$ th heifer $(k=1-82)$ from the $l$ th herd $(l=1-3) ; \beta_{0}$ is the intercept (overall mean); $\beta_{1}$ to $\beta_{8}$ are the regression coefficients of the fixed effects: quarter-level IMI status on sampling day, quarter position, herd, AS function terms 1 to 4, and the natural logarithm of the qSCC at sampling day, respectively; $\mu_{\text {Heifer } k l(j)}$ is the random effect of the heifer $k$ from herd $l$ to correct for clustering of quarters within heifer; $\mu_{Q \text { uarter } j k l(i)}$ is the random effect to correct for within-quarter correlation of subsequent biweekly sampling days $i$ (repeated statement) for quarter $j$ of heifer $k$ from herd $l$; and $\mathrm{e}_{i j k l}$ is the random error term.
The AS function terms 1 to 4 are $(t / 130),(t / 130)^{2}$, $\ln (130 / t)$, and $[\ln (130 / t)]^{2}$, respectively, where $t$ is the DIM at the current sampling day and 130 is the maximum follow-up period in days in this study.

\section{RESULTS}

\section{NAS Species Distribution}

From the 82 heifers included in this study, 324 quarters were eligible for sampling on the first sampling day (1-4 DIM). Four quarters were not eligible because they were nonfunctional or had CM on the first sampling day. In total, 304 isolates could be phenotypically identified as NAS and further identified to the species level (Table 1) across the sampling days. Seventeen different NAS species were cultured. Staphylococcus chromogenes was the most prevalent species (52\%). Staphylococcus epidermidis could not be isolated on the first sampling day although it was the second most prevalent species $(9.2 \%)$ during the entire follow-up period, followed by $S$. xylosus $(8.2 \%)$ and $S$. equorum $(5.9 \%)$. Thirteen other species had a prevalence of less than $5 \%$. On the first sampling day, 13 different NAS species were isolated, whereas the number of NAS species ranged between 7 and 11 for sampling d 2 to 10 . Also, $17.8 \%$ of the quarters had an IMI with a NAS species on sampling d 1, whereas this was between 6.9 and $10.5 \%$ on the later sampling days. Most of the NAS species with the highest prevalence (e.g., S. chromo-

\begin{tabular}{|c|c|c|c|c|c|c|c|c|c|c|c|c|}
\hline NAS species & \multicolumn{10}{|c|}{ Sampling day (DIM) } & Total & $\begin{array}{c}\text { Total } \\
(\%)\end{array}$ \\
\hline S. epidermidis & - & 3 & 2 & 3 & 3 & 3 & 6 & 3 & 2 & 3 & 28 & 9.2 \\
\hline S. xylosus & 7 & 4 & 2 & 2 & 3 & 1 & 1 & 2 & 1 & 2 & 25 & 8.2 \\
\hline S. equorum & 3 & 2 & 2 & 2 & 1 & 3 & 2 & 2 & 1 & - & 18 & 5.9 \\
\hline S. hominis & 1 & 1 & 1 & - & 1 & - & 2 & - & 3 & - & 9 & 3.0 \\
\hline S. vitulinus & 6 & - & - & - & 1 & - & 1 & - & - & - & 8 & 2.6 \\
\hline S. sciuri & 6 & - & - & - & 1 & - & - & - & - & - & 7 & 2.3 \\
\hline S. pulvereri & 3 & - & 1 & - & 2 & - & 1 & - & - & - & 7 & 2.3 \\
\hline S. arlettae & 1 & - & 1 & - & - & 1 & - & 1 & 1 & 1 & 6 & 2.0 \\
\hline S. cohnii & 1 & - & - & 1 & - & - & 1 & - & 2 & - & 5 & 1.6 \\
\hline S. warneri & - & - & - & - & - & - & - & 1 & 1 & 1 & 3 & 1.0 \\
\hline Total (\%) & 17.8 & 9.5 & 10.5 & 9.2 & 10.2 & 7.9 & 10.5 & 8.2 & 9.2 & 6.9 & 100 & \\
\hline
\end{tabular}
genes, S. epidermidis, S. xylosus, and S. equorum) were

Table 1. Overview of NAS (Staphylococcus) species distribution from sampling d 1 (1-4 DIM) to 10 (127-130 DIM) of 324 quarters from 82 dairy heifers in 3 commercial dairy herds 
found throughout the entire follow-up period, whereas most of the less-prevalent species were predominantly found either before (e.g., S. vitulinus, S. sciuri, and $S$. pulvereri) or after (e.g., S. arlettae, S. cohnii, and $S$. warneri) the first 60 DIM.

\section{Prevalence of IMI with NAS}

On the first sampling day, 65 (20.1\%) of the 324 quarters were infected (i.e., having a tIMI or pIMI) with S. chromogenes $(\mathrm{n}=20)$, other NAS species (n $=36)$, or a major pathogen $(\mathrm{n}=9)$, and $220(67.9 \%)$ were noninfected, whereas the IMI status was undefined for 39 (12.0\%) quarters (Table 2). The number of quarters having an infection at sampling d 2 to 9 ranged between 12 and 14\%, whereas the number of quarters not yielding any pathogen (i.e., noninfected quarters and quarters having a cIMI) ranged between 63.2 and $68.6 \%$ on those sampling days. On sampling d 10, relatively more quarters had an undefined IMI status because a subsequent sampling day was lacking to correctly define the exact IMI status.

The first tIMI and pIMI episodes with either S. chromogenes or the group of other NAS species were first diagnosed on the first sampling day. The number of tIMI with $S$. chromogenes and other NAS species was the highest on the first sampling day compared with all later sampling days. During the entire follow-up period, 142 NAS IMI were diagnosed in 116 of the 324 quarters (52 front quarters vs. 64 hind quarters) from 64 of the 82 heifers included in this study.

Half of the tIMI with $S$. chromogenes $(\mathrm{n}=22)$ started between 1 and 4 DIM, and the last case was estimated to have started on 78 DIM (Table 3). In contrast, new pIMI with $S$. chromogenes were almost exclusively diagnosed on the first and second sampling days: 9 $(50 \%)$ and $8(44.4 \%)$ out of 18 episodes, respectively. The average DIM at the start of a new case was $6.2 \mathrm{~d}$, and no new pIMI with $S$. chromogenes were diagnosed after 36 DIM. Out of 92 tIMI with NAS other than S. chromogenes, $34(37 \%)$ and $6(6.5 \%)$ were first diagnosed on sampling d 1 and 2, respectively, whereas $44(47.8 \%)$ tIMI were diagnosed after 40 DIM. New tIMI with this group of NAS other than S. chromogenes started on average on 38.8 DIM, and pIMI episodes at 35.4 DIM. For both categories, the last IMI were estimated to have started on approximately 109 and 107 DIM, respectively.

\section{Persistence of IMI with NAS}

Of the 20 quarters that were infected with S. chromogenes on the first sampling day, $11(55 \%)$ were no longer infected with this pathogen on the second sampling

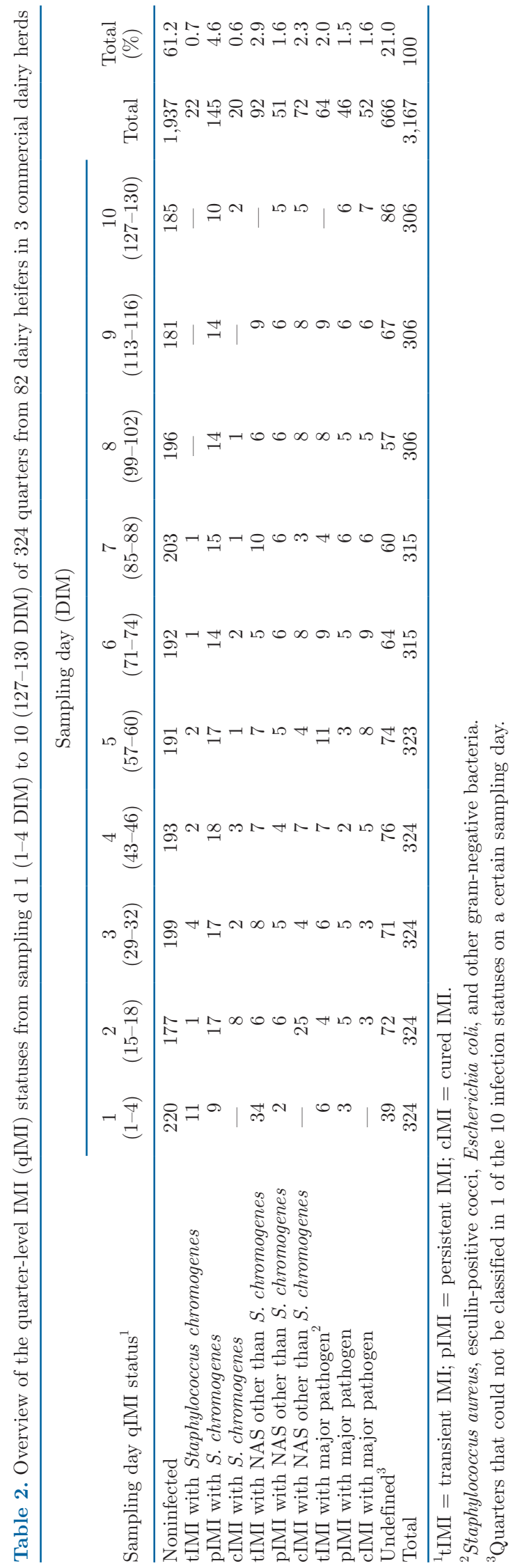


day, whereas 9 quarters (45\%) were having a pIMI episode. For NAS species other than S. chromogenes, only $2(5.6 \%)$ of the 36 quarters had a pIMI episode; in the other $34(94.4 \%)$ quarters, the same NAS species was no longer found on the second sampling day (Table 3).

During the entire study, S. chromogenes caused 22 tIMI and 18 pIMI episodes (Table 3). In contrast, NAS other than $S$. chromogenes caused 92 tIMI and 10 pIMI episodes.

The average duration of pIMI episodes with S. chromogenes was 110.4 d (range: 49.0 to 134.0 d; i.e., the duration of the entire follow-up period; Table 4). The pIMI episodes with NAS other than $S$. chromogenes had an average duration of $70.0 \mathrm{~d}$, with a minimum and maximum of 21.0 and $133.0 \mathrm{~d}$, respectively. The episodes that were first diagnosed on sampling $\mathrm{d} 1$ and 2 had an average duration of 77.0 and $94.5 \mathrm{~d}$, respectively, whereas the duration of episodes diagnosed after 50 DIM varied between 28.0 and $56.0 \mathrm{~d}$ on average.

\section{Effect of tIMI, pIMI, and cIMI on qSCC}

Quarter position was not significantly associated with qLnSCC and was omitted from the model. The qSCC on sampling day from noninfected quarters $(56,000$ cells $/ \mathrm{mL}$ ) was not different from that of quarters having a tIMI with $S$. chromogenes $(69,000$ cells $/ \mathrm{mL} ; P=$ 0.41 ; Table 5) and was significantly lower than that from quarters having a tIMI with NAS other than $S$. chromogenes or a major pathogen $(82,000$ cells $/ \mathrm{mL}, P$ $=0.003$; and 86,000 cells $/ \mathrm{mL}, P=0.006$, respectively). The sampling day SCC from quarters having a pIMI with $S$. chromogenes, a pIMI with NAS other than $S$. chromogenes, or a pIMI with a major pathogen was significantly higher $(351,000$ cells $/ \mathrm{mL}, P<0.001 ; 213,000$ cells $/ \mathrm{mL}, P<0.001$; and 659,000 cells $/ \mathrm{mL}, P<0.001$, respectively) compared with that of noninfected quarters. The qSCC on sampling days where a quarter was considered cured from an IMI with $S$. chromogenes was still significantly higher $(120,000$ cells $/ \mathrm{mL}, P=0.005)$ compared with that of noninfected quarters, which is remarkable given the fact that 16 of these 20 cIMI followed a tIMI. In quarters that cured from an IMI with NAS other than $S$. chromogenes or a major pathogen, qSCC was not different $(63,000$ cells $/ \mathrm{mL}, P=0.39$; and 67,000 cells $/ \mathrm{mL}, P=0.27$, respectively). The qSCC from quarters having a pIMI with a major pathogen was not significantly different from quarters having a pIMI with $S$. chromogenes $(P=0.36)$, although it was significantly higher than qSCC of quarters with a pIMI with NAS other than $S$. chromogenes $(P=0.002)$. We observed no difference in qSCC between quarters having a pIMI with $S$. chromogenes and quarters having a pIMI with NAS other than $S$. chromogenes $(P=0.99)$. 


\section{Effect of tIMI, pIMI, and cIMI on qMY}

The variable qLnSCC was not significantly associated with qMY and was therefore omitted from the model. The qMY at sampling day was significantly higher in noninfected quarters $(7.40 \mathrm{~kg} / \mathrm{d})$ than in quarters having a pIMI with a major pathogen or a cIMI with $S$. chromogenes $(7.15 \mathrm{~kg} / \mathrm{d}, P=0.04$; Table 6$)$. None of the other IMI statuses resulted in a significantly different qMY compared with noninfected quarters. Hind quarters produced, on average, $0.90 \mathrm{~kg} / \mathrm{d}$ more milk than front quarters $(P<0.001)$.

\section{DISCUSSION}

Because of the diversity of NAS, a group of staphylococci with more than 50 (sub)species (Vanderhaeghen et al., 2015), studies on their association with milk yield have reached contradictory conclusions. Part of the discrepancies among different studies can be attributed partly to the great variation in study design, such as length of the follow-up period, number of herds and animals, definition of IMI, and selection of included animals (e.g., heifers vs. multiparous cows, animals at the start of lactation vs. any lactation stage) but also the identification methods (i.e., phenotypic vs. genotypic methods). In our previous work, we documented that NAS IMI between 1 and 4 DIM and in the first 18 DIM resulted in a higher qSCC during the first 4 mo of lactation, but had no effect on qMY (Valckenier et al., 2019, 2020). However, we observed a difference between $S$. chromogenes and other NAS species in terms of occurrence, persistence, and effect of IMI in the first $18 \mathrm{~d}$ after calving on later qSCC and qMY. The aim of this study was to further elaborate on the infection dynamics of NAS IMI in the first 130 DIM and on the effect of NAS IMI on qSCC and qMY during this period. The prevalence and persistence of NAS IMI have been studied extensively in primiparous and multiparous cows, although no qMY data were available in those studies. This is, to the best of our knowledge, the first study to follow quarter IMI status, qSCC, and qMY for several months.

We observed 142 NAS IMI in 116 out of 324 quarters. This is considerably higher than in the study of Taponen et al. (2007), wherein 63 of 328 quarters were infected with NAS. Interestingly, the heifers that had a NAS IMI in that study were infected in 2.9 quarters, on average, whereas the heifers in our study had a NAS IMI case in 1.8 quarters on average (data not shown), a finding that might relate to the use of AMS in our study. A significant increase in subclinical mastitis caused by NAS was demonstrated in 18 Danish herds after the introduction of an AMS, and the teat cleaning device 
Table 5. Final linear mixed regression model describing the association between the natural log-transformed quarter milk SCC (qLnSCC; outcome variable) and quarter-level IMI status (main predictor of interest) during the first 130 DIM of 324 quarters from 82 dairy heifers in 3 commercial dairy herds

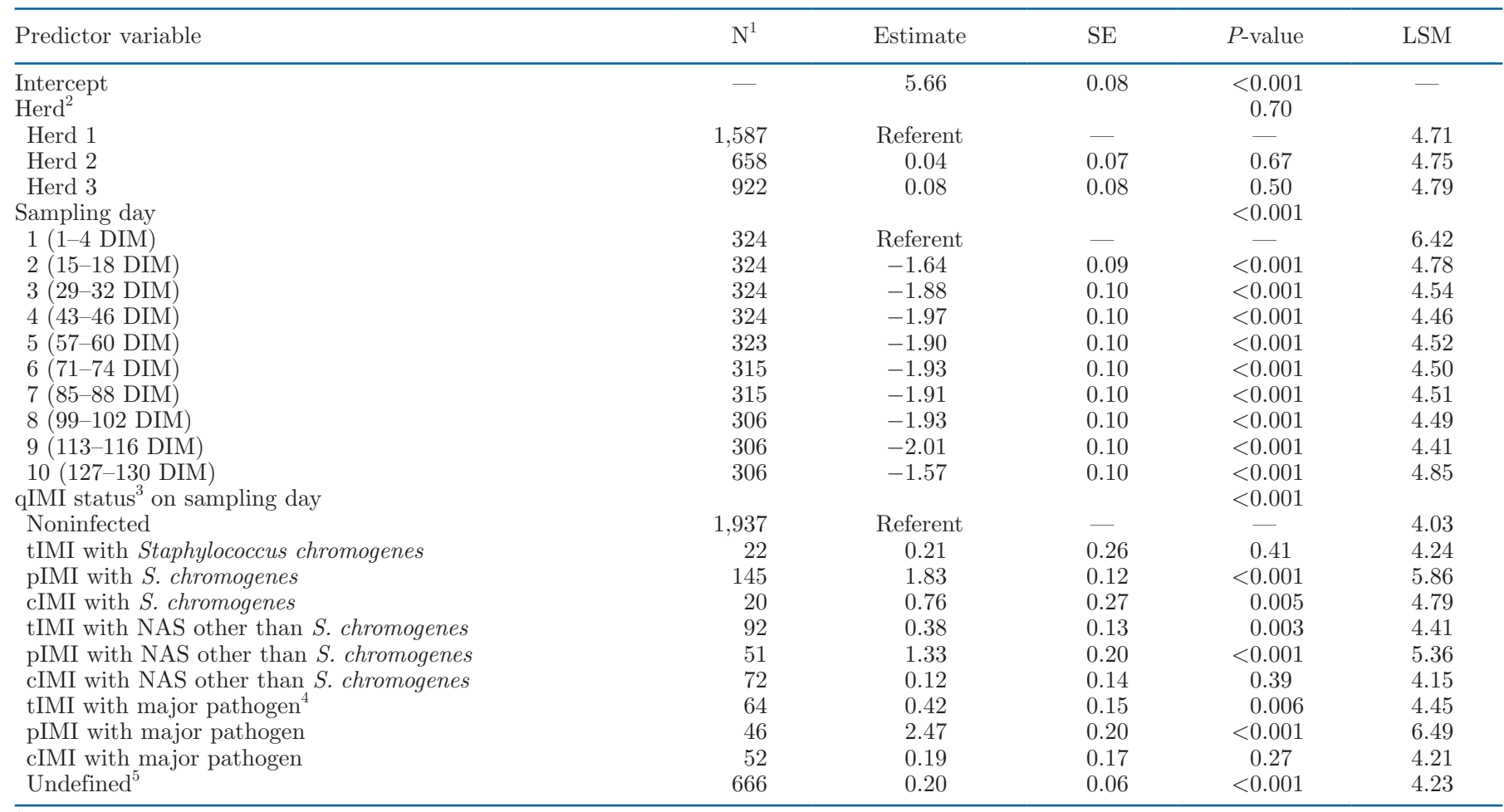

${ }^{1}$ Number of measurements.

${ }^{2}$ Herd was forced in the model to correct for potential clustering of heifers within herds.

${ }^{3}$ tIMI $=$ transient IMI; pIMI = persistent IMI; cIMI = cured IMI.

${ }^{4}$ Staphylococcus aureus, esculin-positive cocci, Escherichia coli, and other gram-negative bacteria.

${ }^{5}$ Quarters that could not be classified as 1 of the 10 infection statuses on a certain sampling day.

was thought to play a role in the increased transmission of pathogens (Pedersen and Bennedsgaard, 2006). Also, in an AMS, a single milking unit is in more intensive use and comes into contact with the teats of all animals in a group at least 2 times per day. Furthermore, the automatic cleaning of the teats is standardized and thus not adapted to the dirtiness of individual animals (Dohmen et al., 2010); the use of automatic postmilking teat spray is often less thorough and precise (Rasmussen and Hemling, 2002), potentially allowing more teat skin colonization. The fact that $S$. equorum, a typical environmental NAS species (Piessens et al., 2011), was the fourth most common species in the current study might be an indication of such an effect.

The number of different NAS species isolated from milk samples during this study $(\mathrm{n}=17)$ is in line with other recent studies (De Visscher et al., 2014, 2016; Mahmmod et al., 2018). The most common NAS species in our study was S. chromogenes. This appears to be the predominant species in most parts of the world (Taponen et al., 2007; Fry et al., 2014; Tomazi et al., 2015), although the distribution of NAS species has been shown to differ greatly between herds (De Visscher et al., 2016; Condas et al., 2017; Dolder et al., 2017; Mahmmod et al., 2018).

Despite the overall mild effect on udder health, it has been shown that NAS possess the ability to cause persistent IMI for longer periods (Taponen et al., 2007; Supré et al., 2011; Mørk et al., 2012). The proportion of NAS IMI that persists varies greatly between different studies: from 33\% (Nyman et al., 2018) and $46 \%$ (Taponen et al., 2007) up to $85 \%$ (Timms and Schultz, 1987; Chaffer et al., 1999). This is higher than the number of pIMI episodes in our study (19.7\% of 142 NAS episodes). In studies with a longer follow-up period, IMI caused by NAS could persist for at least 40 wk (Taponen et al., 2007), and the mean duration of IMI for all NAS species can be as long as $188 \mathrm{~d}$ (Bexiga et al., 2014). Older studies even found average durations of infections of more than $220 \mathrm{~d}$ (Rainard et al., 1990; Todhunter et al., 1993), although no reliable strain-typing methods were available for confirmation and NAS species were identified based on phenotypic assays. It should be noted that heifers in our study 
Table 6. Final linear mixed regression model using the Ali and Schaeffer (AS) function describing the association between the daily quarter milk yield (outcome variable) and quarter-level IMI status (qIMI; main predictor of interest) during the first 130 DIM of 324 quarters from 82 dairy heifers in 3 commercial dairy herds

\begin{tabular}{|c|c|c|c|c|c|}
\hline Predictor variable & $\mathrm{N}^{1}$ & Estimate & $\mathrm{SE}$ & $P$-value & LSM \\
\hline Herd 1 & 1,587 & Referent & - & - & 7.20 \\
\hline Herd 3 & 922 & 0.41 & 0.26 & 0.11 & 7.61 \\
\hline AS function term ${ }^{3} 1$ & & -14.89 & 1.08 & $<0.001$ & - \\
\hline AS function term 2 & & 4.17 & 0.50 & $<0.001$ & - \\
\hline qIMI status ${ }^{4}$ on sampling day & & & & 0.23 & \\
\hline Noninfected & 1,937 & Referent & - & - & 7.40 \\
\hline tIMI with Staphylococcus chromogenes & 22 & -0.10 & 0.13 & 0.41 & 7.30 \\
\hline pIMI with $S$. chromogenes & 145 & 0.08 & 0.15 & 0.56 & 7.49 \\
\hline cIMI with $S$. chromogenes & 20 & -0.25 & 0.12 & 0.04 & 7.15 \\
\hline tIMI with NAS other than $S$. chromogenes & 92 & -0.06 & 0.06 & 0.36 & 7.35 \\
\hline pIMI with NAS other than $S$. chromogenes & 51 & -0.001 & 0.18 & 0.99 & 7.40 \\
\hline Quarter position & & & & $<0.001$ & \\
\hline Front & 1,598 & Referent & - & - & 6.87 \\
\hline Hind & 1,569 & 0.89 & 0.13 & $<0.001$ & 7.77 \\
\hline
\end{tabular}

${ }^{1}$ Number of measurements.

${ }^{2}$ Herd was forced in the model to correct for potential clustering of heifers within herds.

${ }^{3}$ Term 1: $\mathrm{t} / 130$, where $\mathrm{t}=$ stage of lactation in days; term 2: $(\mathrm{t} / 130)^{2}$; term 3: $\operatorname{Ln}(130 / \mathrm{t}) ; \operatorname{term} 4:[\operatorname{Ln}(130 / \mathrm{t})]^{2}$.

${ }^{4} \mathrm{tIMI}=$ transient IMI; pIMI $=$ persistent IMI; cIMI $=$ cured IMI.

${ }^{5}$ Staphylococcus aureus, esculin-positive cocci, Escherichia coli, and other gram-negative bacteria.

${ }^{6}$ Quarters that could not be classified as 1 of the 10 infection statuses on a certain sampling day.

were followed from calving to 130 DIM, and thus the maximum possible duration of IMI episodes was limited to this time frame. It is possible that IMI that were present at the end of this follow-up period lasted longer than 130 DIM in the current lactation, and potentially even persisted in the next lactation.

More than 10 NAS species are able to cause persistent IMI (Thorberg et al., 2009; Mørk et al., 2012; Fry et al., 2014; Nyman et al., 2018), but the possibility to cause persistent infections varies with species: S. chromogenes and S. xylosus cause more persistent than transient IMI, whereas other NAS species cause relatively more transient infections according to Supré et al. (2011), although that study did not use straintyping as we did. This is in line with the results of our study in regard to S. chromogenes: 18 of the 28 pIMI episodes were caused by this species, whereas the other 10 episodes were caused by other species $(2 S$. xylosus, 1 S. hominis, 1 S. simulans, 4 S. epidermidis, $1 S$. warneri, and 1 S. haemolyticus). Interestingly, Bexiga et al. (2014) found no significant differences in the mean duration of IMI caused by different NAS species. The number of pIMI episodes in our study was too small to reach definitive conclusions at the species level. However, regarding the ability to cause persistent infections, S. chromogenes seemed the best adapted to survive in the udder gland in our study. In addition to potential differences in virulence and adaptation to the udder environment, the same strains of $S$. chromogenes were identified both in mastitic milk and on the udder skin (Taponen et al., 2008). For some NAS species such as $S$. equorum, the teat skin and apex can thus act as a reservoir increasing the odds of IMI in the same quarter (Mahmmod et al., 2018), although several other studies could not demonstrate such an association for the more prevalent species such as $S$. chromogenes, S. cohnii, $S$ epidermidis, and S. xylosus (Quirk et al., 2012; Braem et al., 2013; Mahmmod et al., 2018). However, to the best of our knowledge, no study has yet determined the causal relation between NAS skin colonization and IMI.

Aarestrup and Jensen (1997) showed that infections caused by S. chromogenes in heifers disappeared shortly after parturition. This is in contrast to the behavior of $S$. chromogenes in our study, where 9 out of 20 IMI with this pathogen persisted for, on average, $101 \mathrm{~d}$ and at least $49 \mathrm{~d}$. However, there appeared to be no difference in persistence between the 2 dominant species (i.e., S. chromogenes and S. simulans) in Taponen et al. 
(2007), whereas, in our study, only 2 quarters had an IMI caused by $S$. simulans (i.e., 1 tIMI and 1 pIMI). In general, we found about half of the IMI caused by S. chromogenes persisted compared with only $16.4 \%$ of IMI caused by the other NAS species. Even higher proportions of pIMI by $S$. chromogenes (69.6\%) and other NAS (31.8\%) have been reported (Supré et al., 2011). Differences in persistence of NAS IMI are thus not merely the result of variations in study design and occurrence of certain species, but can vary between different strains of a NAS species (Piccart et al., 2016).

Subclinical infections with NAS result in a moderately elevated qSCC, supporting the NAS group's status as minor pathogens. Because of the small number of IMI caused by other NAS species, our results could not be analyzed per species except for $S$. chromogenes. The qSCC of quarters having a tIMI with $S$. chromogenes was not significantly higher than that of noninfected quarters. On the other hand, tIMI with NAS other than $S$. chromogenes did result in a significantly yet mildly increased qSCC, with a level comparable to that of tIMI with a major pathogen. When IMI with $S$. chromogenes, other NAS, or a major pathogen persisted, qSCC during the infection was significantly elevated, although qSCC of quarters having a pIMI with a major pathogen was not significantly higher compared with S. chromogenes. This, in combination with the large proportions of infections that persist for longer periods, confirms the status of $S$. chromogenes to be "more relevant for udder health," as first proposed by Supré et al. (2011) and substantiated by De Visscher et al. (2016) and Fry et al. (2014). Interestingly, qSCC during pIMI and tIMI with NAS were much lower than the values estimated by Taponen et al. (2007) (geometric mean qSCC of 657,600 and 649,100 cells/mL, respectively). For $S$. chromogenes, further investigation is needed to determine whether the strains that cause tIMI without elevated qSCC are different from the strains causing pIMI with a significantly higher qSCC, or that other factors, such as the immunity of the quarter or animal, play a role.

The association between the different IMI statuses and qMY throughout the first 130 DIM was modeled using the 4-parametric AS function. The normal lactation curve of dairy cows is characterized by a steep increase in early lactation and a slower decrease thereafter, thus requiring nonlinear models to predict MY. Several mathematical models were described to predict the lactation curves based on milk yield records. Seconddegree polynomial functions, such as the 4-parametric AS function, fitted the lactation curve better than others (Ali and Schaeffer, 1987; van der Poel et al., 1995). Compared with 6 other models, the AS model had the highest square of the correlation coefficient between actual milk yield and predicted milk yield, lowest root mean squared error, and smallest differences between actual and predicted lactation milk yield (Kocak and Ekiz, 2008). Several other studies have confirmed that this AS function is very suitable for modeling lactation curves (Buttchereit et al., 2010; Stamer et al., 2011; Melzer et al., 2017).

We can conclude that the MY of quarters having an IMI with either $S$. chromogenes or other NAS species, either transient or persistent, is not different from that of noninfected quarters, despite the elevated qSCC. Given the strong negative correlation between MY and SCC under virtually all circumstances, this is an important result in these data. Despite the presence of an inflammatory response, as shown by the elevated SCC, NAS-infected quarters do not show lower milk production. However, one of the main limitations of our study was the inability to distinguish between teat canal colonization and IMI with NAS, meaning that some of the positive bacteriological examinations will have been the result of teat canal colonization instead of IMI. One option to distinguish between IMI (which causes inflammation and therefore an elevation of the SCC) and teat canal colonization in case of a positive bacteriological examination is to include a certain SCC limit in the IMI definition. We were unable to decide on such a SCC threshold because it would have been impossible to study the effect of a NAS IMI on SCC (e.g., if the qSCC had to be at least 200,000 cells/mL before considering a culture-positive quarter to be truly NAS infected, NAS-infected quarters would always have had an elevated SCC). Other possibilities to consider in future research are to collect duplicate milk samples (Dohoo et al., 2011a), taking milk samples via puncture of the udder wall with a needle (Hiitiö et al., 2016) or via a sterile teat cannula (Friman et al., 2017), or to use another inflammatory parameter that would represent tissue damage, such as $N$-acetyl- $\beta$-D-glucosaminidase (Hovinen et al., 2016). Furthermore, we acknowledge that the detection of CM cases, and especially the mild cases with only changes in milk composition, are a challenge in AMS. It is thus possible that a few of these mild cases remained undetected and were not reported, which might have influenced the analysis of their effect on udder health and milk production. Because of the high number of NAS species identified in our study ( $\mathrm{n}=17$ ) and the relatively low number of isolates of most NAS species, the effect on qSCC and qMY could not be analyzed per species, with the exception of $S$. chromogenes.

Remarkably, quarters that cured from an IMI with $S$. chromogenes had a significantly lower qMY immediately after the pIMI. Interestingly, a higher MY associated with NAS IMI was only found in studies 
where MY was measured at the animal level (Wilson et al., 1997; Schukken et al., 2009; Thorberg et al., 2009; Piepers et al., 2010, 2013). One explanation for the different conclusions might be the aggregation of different IMI statuses of each quarter, resulting in an IMI status at the cow level that does not necessarily represent the IMI status of all quarters of that animal (e.g., an animal could be considered as NAS infected if 1 quarter had a NAS IMI, although the 3 other quarters could be noninfected). Another possible explanation is the impossibility of quantifying the physiologically higher milk production of hind quarters when MY is only measured at the animal level, whereas NAS IMI occurred slightly more often in hind quarters in our study. A positive effect of NAS IMI on MY cannot be found when MY is measured on the quarter level (Tomazi et al., 2015; Valckenier et al., 2019, 2020), although the elevated qSCC also does not result in a lower qMY. A drawback of these studies is that, in contrast to studies measuring MY at the animal level, no longitudinal follow-up of the quarter IMI status was performed, unlike what was done in the current study.

The conclusion that NAS IMI cause a mild inflammatory reaction with a significantly higher qSCC but have no effect on qMY remains intriguing. Structural equation models (Gianola and Sorensen, 2004), which facilitate modeling the simultaneous and recursive effects between phenotypic characteristics, have described 3 main effects that play a role in the relationship between MY and SCC. The infection effect results in a decrease of MY in cows with a higher SCC. Higherproducing cows are more susceptible to IMI, and this stress effect thus results in a higher SCC. Finally, the dilution effect in higher-yielding animals results in a lower SCC (Wu et al., 2007; Jamrozik et al., 2010). No general consensus seems to be found, although most studies have concluded that a model with a negative effect of SCC on MY is favorable (de los Campos et al., 2006; Jamrozik and Schaeffer, 2010), and this in combination with a smaller but positive effect of a higher SCC on MY (Wu et al., 2007; Jamrozik et al., 2010). These effects are larger in the first 60 DIM compared with the period between 61 and 120 DIM (Wu et al., 2007). According to the aforementioned conclusions from structural equation models, we would expect IMI with NAS, resulting in an increased qSCC, to be negatively associated with qMY. The existence of such an underlying positive effect between SCC and MY might explain the positive effect of NAS IMI on MY that has been observed in some studies (Piepers et al., 2010, 2013), although other confounding factors, such as a lower incidence of CM in NAS-infected quarters due to protective effects of pre-existing NAS IMI against new IMI caused by major pathogens, should be ruled out first. In the case of IMI with NAS, the underlying negative infection effect might be so small that it had no measurable impact on the association between qSCC and $\mathrm{qMY}$, or the negative effect of infection could be of equal magnitude to the positive effect of SCC on MY, resulting in no overall effect on MY. In relation to this, we found that tIMI or pIMI with $S$. chromogenes had no significant effect on qMY but, remarkably, a cIMI resulted in a significantly lower qMY than that of noninfected quarters. Further research should study whether the positive effect on MY due to the presence of this bacterium has disappeared in this situation, which leaves only the negative infection effect and thus a lower MY. Based on our results (i.e., NAS IMI cause a significantly higher SCC in infected quarters without a negative effect on qMY), NAS can be considered minor pathogens. If the underlying cause of the positive effect between SCC and MY can be identified (e.g., protective effects against major pathogen IMI or even production stimulating effects due to some specific NAS strains), this could open perspectives for developing new prevention or treatment concepts in the fight against mastitis.

\section{CONCLUSIONS}

The prevalence of NAS is high in early lactating dairy heifers. Most NAS infections seem to be caused by $S$. chromogenes. The persistence of NAS IMI depends on the NAS species involved. About half of the IMI caused by $S$. chromogenes persisted, whereas only $9.8 \%$ of the IMI caused by other NAS species persisted. Quarters having a persistent IMI caused by $S$. chromogenes and by the group of other NAS species had a higher SCC than quarters that were transiently infected. However, neither transient nor persistent IMI with NAS were significantly associated with qMY during the first 130 DIM.

\section{ACKNOWLEDGMENTS}

The farmers who cooperated in this work are gratefully acknowledged. The MALDI-TOF MS was financed by the Research Foundation Flanders (FWO-Vlaanderen) as Hercules project [G0H2516N, AUGE/15/05]. None of the authors have a financial or personal relationship with other people or organizations that could inappropriately influence or bias the content of the paper.

\section{REFERENCES}

Aarestrup, F. M., and N. E. Jensen. 1997. Prevalence and duration of intramammary infection in Danish heifers during the peripartum period. J. Dairy Sci. 80:307-312. https://doi.org/10.3168/jds .S0022-0302(97)75939-3. 
Adkins, P. R. F., J. R. Middleton, M. J. Calcutt, G. C. Stewart, and L. K. Fox. 2017. Species identification and strain typing of Staphylococcus agnetis and Staphylococcus hyicus isolates from bovine milk by use of a novel multiplex PCR assay and pulsed-field gel electrophoresis. J. Clin. Microbiol. 55:1778-1788. https://doi.org/ 10.1128/JCM.02239-16.

Ali, T. E., and L. R. Schaeffer. 1987. Accounting for covariances among test day milk yields in dairy cows. Can. J. Anim. Sci. 67:637-644. https://doi.org/10.4141/cjas87-067.

Bexiga, R., M. G. Rato, A. Lemsaddek, T. Semedo-Lemsaddek, C. Carneiro, H. Pereira, D. J. Mellor, K. A. Ellis, and C. L. Vilela. 2014. Dynamics of bovine intramammary infections due to coagulase-negative staphylococci on four farms. J. Dairy Res. 81:208214. https://doi.org/10.1017/S0022029914000041.

Braem, G., S. De Vliegher, B. Verbist, V. Piessens, E. Van Coillie, L. De Vuyst, and F. Leroy. 2013. Unraveling the microbiota of teat apices of clinically healthy lactating dairy cows, with special emphasis on coagulase-negative staphylococci. J. Dairy Sci. 96:1499-1510. https://doi.org/10.3168/jds.2012-5493.

Brunton, L. A., D. Duncan, N. G. Coldham, L. C. Snow, and J. R. Jones. 2012. A survey of antimicrobial usage on dairy farms and waste milk feeding practices in England and Wales. Vet. Rec. 171:296. https://doi.org/10.1136/vr.100924.

Buttchereit, N., E. Stamer, W. Junge, and G. Thaller. 2010. Evaluation of five lactation curve models fitted for fat:protein ratio of milk and daily energy balance. J. Dairy Sci. 93:1702-1712. https:/ /doi.org/10.3168/jds.2009-2198.

Cameron, M., H. Barkema, J. De Buck, S. De Vliegher, M. Chaffer, J. Lewis, and G. Keefe. 2017. Identification of bovine-associated coagulase-negative staphylococci by matrix-assisted laser desorption/ionization time-of-flight mass spectrometry using a direct transfer protocol. J. Dairy Sci. 100:2137-2147. https://doi.org/10 $.3168 / j d s .2016-12020$.

Chaffer, M., G. Leitner, M. Winkler, A. Glickman, O. Krifucks, E. Ezra, and A. Saran. 1999. Coagulase-negative staphylococci and mammary gland infections in cows. Zentralbl. Veterinarmed. B 46:707-712. https://doi.org/10.1046/j.1439-0450.1999.00289.x.

Compton, C. W. R., C. Heuer, K. Parker, and S. McDougall. 2007. Epidemiology of mastitis in pasture-grazed peripartum dairy heifers and its effects on productivity. J. Dairy Sci. 90:4157-4170. https://doi.org/10.3168/jds.2006-880.

Condas, L. A. Z., J. De Buck, D. B. Nobrega, D. A. Carson, J.-P. Roy, G. P. Keefe, T. J. DeVries, J. R. Middleton, S. Dufour, and H. W. Barkema. 2017. Distribution of non-aureus staphylococci species in udder quarters with low and high somatic cell count, and clinical mastitis. J. Dairy Sci. 100:5613-5627. https://doi.org/10.3168/jds 2016-12479.

de los Campos, G., D. Gianola, and B. Heringstad. 2006. A structural equation model for describing relationships between somatic cell score and milk yield in first-lactation dairy cows. J. Dairy Sci. 89:4445-4455. https://doi.org/10.3168/jds.S0022-0302(06)72493 $-6$.

De Visscher, A., S. Piepers, F. Haesebrouck, and S. De Vliegher. 2016. Intramammary infection with coagulase-negative staphylococci at parturition: Species-specific prevalence, risk factors, and effect on udder health. J. Dairy Sci. 99:6457-6469. https://doi.org/10.3168/ jds.2015-10458.

De Visscher, A., S. Piepers, F. Haesebrouck, K. Supré, and S. De Vliegher. 2017. Coagulase-negative staphylococcus species in bulk milk: Prevalence, distribution, and associated subgroup- and species-specific risk factors. J. Dairy Sci. 100:629-642. https://doi .org/10.3168/jds.2016-11476.

De Visscher, A., S. Piepers, K. Supré, F. Haesebrouck, and S. De Vliegher. 2015. Short communication: Species group-specific predictors at the cow and quarter level for intramammary infection with coagulase-negative staphylococci in dairy cattle throughout lactation. J. Dairy Sci. 98:5448-5453. https://doi.org/10.3168/jds .2014-9088.

De Visscher, A., K. Supre, F. Haesebrouck, R. N. Zadoks, V. Piessens, E. Van Coillie, S. Piepers, and S. De Vliegher. 2014. Further evidence for the existence of environmental and host-associated species of coagulase-negative staphylococci in dairy cattle. Vet. Microbiol. 172:466-474. https://doi.org/10.1016/j.vetmic.2014.06 .011 .

De Vliegher, S., L. K. K. Fox, S. Piepers, S. McDougall, and H. W. W. Barkema. 2012. Invited review: Mastitis in dairy heifers: Nature of the disease, potential impact, prevention, and control. J. Dairy Sci. 95:1025-1040. https://doi.org/10.3168/jds.2010-4074.

Dohmen, W., F. Neijenhuis, and H. Hogeveen. 2010. Relationship between udder health and hygiene on farms with an automatic milking system. J. Dairy Sci. 93:4019-4033. https://doi.org/10.3168/ jds.2009-3028.

Dohoo, I., S. Andersen, R. Dingwell, K. Hand, D. Kelton, K. Leslie, Y. Schukken, and S. Godden. 2011a. Diagnosing intramammary infections: Comparison of multiple versus single quarter milk samples for the identification of intramammary infections in lactating dairy cows. J. Dairy Sci. 94:5515-5522. https://doi.org/10.3168/jds.2011 -4486 .

Dohoo, I. R. R., J. Smith, S. Andersen, D. F. F. Kelton, and S. Godden., and Mastitis Research Workers' Conference. 2011b. Diagnosing intramammary infections: Evaluation of definitions based on a single milk sample. J. Dairy Sci. 94:250-261. https://doi.org/10 $.3168 / j d s .2010-3559$.

Dolder, C., B. H. P. van den Borne, J. Traversari, A. Thomann, V. Perreten, and M. Bodmer. 2017. Quarter- and cow-level risk factors for intramammary infection with coagulase-negative staphylococci species in Swiss dairy cows. J. Dairy Sci. 100:5653-5663. https://doi.org/10.3168/jds.2016-11639.

Friman, M., H. Hiitiö, M. Niemi, J. Holopainen, S. Pyörälä, and H. Simojoki. 2017. The effect of a cannula milk sampling technique on the microbiological diagnosis of bovine mastitis. Vet. J. 226:57-61. https://doi.org/10.1016/j.tvjl.2017.07.003.

Fry, P. R. R., J. R. R. Middleton, S. Dufour, J. Perry, D. Scholl, and I. Dohoo. 2014. Association of coagulase-negative staphylococcal species, mammary quarter milk somatic cell count, and persistence of intramammary infection in dairy cattle. J. Dairy Sci. 97:48764885. https://doi.org/10.3168/jds.2013-7657.

Gianola, D., and D. Sorensen. 2004. Quantitative genetic models for describing simultaneous and recursive relationships between phenotypes. Genetics 167:1407-1424. https://doi.org/10.1534/ genetics.103.025734.

Gröhn, Y. T., D. J. Wilson, R. N. González, J. A. Hertl, H. Schulte, G. Bennett, and Y. H. Schukken. 2004. Effect of pathogen-specific clinical mastitis on milk vield in dairy cows. J. Dairy Sci. 87:33583374. https://doi.org/10.3168/jds.S0022-0302(04)73472-4.

Heikkilä, A.-M., E. Liski, S. Pyörälä, and S. Taponen. 2018. Pathogen-specific production losses in bovine mastitis. J. Dairy Sci. 101:9493-9504. https://doi.org/10.3168/jds.2018-14824.

Hiitiö, H., H. Simojoki, P. Kalmus, J. Holopainen, S. Pyörälä, and S. Taponen. 2016. The effect of sampling technique on PCRbased bacteriological results of bovine milk samples. J. Dairy Sci. 99:6532-6541. https://doi.org/10.3168/jds.2015-10811.

Hogan, J. S., R. N. Gonzales, R. J. Harmon, S. C. Nickerson, S. P. Oliver, J. W. Pankey, and K. L. Smith. 1999. Laboratory Handbook on Bovine Mastitis. National Mastitis Council, Madison, WI.

Hogan, J. S., D. G. White, and J. W. Pankey. 1987. Effects of teat dipping on intramammary infections by staphylococci other than Staphylococcus aureus. J. Dairy Sci. 70:873-879. https://doi.org/ 10.3168/jds.S0022-0302(87)80086-3.

Hovinen, M., H. Simojoki, R. Pösö, J. Suolaniemi, P. Kalmus, L. Suojala, and S. Pyörälä. 2016. N-acetyl- $\beta$-D-glucosaminidase activity in cow milk as an indicator of mastitis. J. Dairy Res. 83:219-227. https://doi.org/10.1017/S0022029916000224.

Jamrozik, J., J. Bohmanova, and L. R. Schaeffer. 2010. Relationships between milk yield and somatic cell score in Canadian Holsteins from simultaneous and recursive random regression models. J. Dairy Sci. 93:1216-1233. https://doi.org/10.3168/jds.2009-2585.

Jamrozik, J., and L. R. Schaeffer. 2010. Recursive relationships between milk yield and somatic cell score of Canadian Holsteins from finite mixture random regression models. J. Dairy Sci. 93:54745486. https://doi.org/10.3168/jds.2010-3470. 
Katholm, J., T. W. Bennedsgaard, M. T. Koskinen, and E. Rattenborg. 2012. Quality of bulk tank milk samples from Danish dairy herds based on real-time polymerase chain reaction identification of mastitis pathogens. J. Dairy Sci. 95:5702-5708. https://doi.org/ 10.3168/jds.2011-5307.

Kocak, O., and B. Ekiz. 2008. Comparison of different lactation curve models in Holstein cows raised on a farm in the South-Eastern Anatolia region. Arch. Tierzucht 51:329-337. https://doi.org/10 $.5194 /$ aab-51-329-2008.

Mahmmod, Y. S., I. C. Klaas, L. Svennesen, K. Pedersen, and H. Ingmer. 2018. Communications of Staphylococcus aureus and non-aureus Staphylococcus species from bovine intramammary infections and teat apex colonization. J. Dairy Sci. 101:7322-7333. https:// doi.org/10.3168/jds.2017-14311.

Matthews, K. R., R. J. Harmon, and B. E. Langlois. 1992. Prevalence of Staphylococcus species during the periparturient period in primiparous and multiparous cows. J. Dairy Sci. 75:1835-1839. https: //doi.org/10.3168/jds.S0022-0302(92)77942-9.

Melzer, N., S. Trißl, and G. Nürnberg. 2017. Short communication: Estimating lactation curves for highly inhomogeneous milk yield data of an $\mathrm{F}_{2}$ population (Charolais $\times$ German Holstein). J. Dairy Sci. 100:9136-9142. https://doi.org/10.3168/jds.2017-12772.

Mørk, T., H. J. Jørgensen, M. Sunde, B. Kvitle, S. Sviland, S. Waage, and T. Tollersrud. 2012. Persistence of staphylococcal species and genotypes in the bovine udder. Vet. Microbiol. 159:171-180. https: //doi.org/10.1016/j.vetmic.2012.03.034.

Nyman, A.-K., C. Fasth, and K. Persson Waller. 2018. Intramammary infections with different non-aureus staphylococci in dairy cows. J. Dairy Sci. 101:1403-1418. https://doi.org/10.3168/jds.2017-13467.

Paradis, M. E., E. Bouchard, D. T. Scholl, F. Miglior, and J. P. Roy. 2010. Effect of nonclinical Staphylococcus aureus or coagulase-negative staphylococci intramammary infection during the first month of lactation on somatic cell count and milk yield in heifers. J. Dairy Sci. 93:2989-2997. https://doi.org/10.3168/jds.2009-2886.

Pearson, L. J., J. H. Williamson, S.-A. Turner, S. J. Lacy-Hulbert, and J. E. Hillerton. 2013. Peripartum infection with Streptococcus uberis but not coagulase-negative staphylococci reduced milk production in primiparous cows. J. Dairy Sci. 96:158-164. https:/ /doi.org/10.3168/jds.2012-5508.

Pedersen, L. H., and T. W. Bennedsgaard. 2006. Udder health in dairy herds converting to automatic milking systems - Bacteriology and cell count pattern. Pages 26-31 in Proc. Cattle Consulting Days 2006, Nyborg, Frederiksberg Bogtrykkeri, Denmark.

Piccart, K., J. Verbeke, A. De Visscher, S. Piepers, F. Haesebrouck, and S. De Vliegher. 2016. Local host response following an intramammary challenge with Staphylococcus fleurettii and different strains of Staphylococcus chromogenes in dairy heifers. Vet. Res. 47:56-67. https://doi.org/10.1186/s13567-016-0338-9.

Piepers, S., L. De Meulemeester, A. De Kruif, G. Opsomer, H. W. Barkema, and S. De Vliegher. 2007. Prevalence and distribution of mastitis pathogens in subclinically infected dairy cows in Flanders, Belgium. J. Dairy Res. 74:478-483. https://doi.org/10.1017/ S0022029907002841.

Piepers, S., G. Opsomer, H. W. W. Barkema, A. de Kruif, and S. De Vliegher. 2010. Heifers infected with coagulase-negative staphylococci in early lactation have fewer cases of clinical mastitis and higher milk production in their first lactation than noninfected heifers. J. Dairy Sci. 93:2014-2024. https://doi.org/10.3168/jds .2009-2897.

Piepers, S., Y. H. H. Schukken, P. Passchyn, and S. De Vliegher. 2013. The effect of intramammary infection with coagulase-negative staphylococci in early lactating heifers on milk yield throughout first lactation revisited. J. Dairy Sci. 96:5095-5105. https://doi .org/10.3168/jds.2013-6644.

Piessens, V., S. De Vliegher, B. Verbist, G. Braem, A. Van Nuffel, L. De Vuyst, M. Heyndrickx, and E. Van Coillie. 2012. Intra-species diversity and epidemiology varies among coagulase-negative Staphylococcus species causing bovine intramammary infections. Vet. Microbiol. 155:62-71. https://doi.org/10.1016/j.vetmic.2011 .08 .005
Piessens, V., E. Van Coillie, B. Verbist, K. Supré, G. Braem, A. Van Nuffel, L. De Vuyst, M. Heyndrickx, and S. De Vliegher. 2011. Distribution of coagulase-negative Staphylococcus species from milk and environment of dairy cows differs between herds. J. Dairy Sci. 94:2933-2944. https://doi.org/10.3168/jds.2010-3956.

Pitkälä, A., M. Haveri, S. Pyörälä, V. Myllys, and T. Honkanen-Buzalski. 2004. Bovine mastitis in Finland 2001-Prevalence, distribution of bacteria, and antimicrobial resistance. J. Dairy Sci. 87:2433-2441. https://doi.org/10.3168/jds.S0022-0302(04)73366 -4 .

Pyörälä, S., and S. Taponen. 2009. Coagulase-negative staphylococciEmerging mastitis pathogens. Vet. Microbiol. 134:3-8. https://doi .org/10.1016/j.vetmic.2008.09.015.

Quirk, T., L. K. Fox, D. D. Hancock, J. Capper, J. Wenz, and J. Park. 2012. Intramammary infections and teat canal colonization with coagulase-negative staphylococci after postmilking teat disinfection: Species-specific responses. J. Dairy Sci. 95:1906-1912. https: //doi.org/10.3168/jds.2011-4898.

Rainard, P., M. Ducelliez, and B. Poutrel. 1990. The contribution of mammary infections by coagulase-negative staphylococci to the herd bulk milk somatic cell count. Vet. Res. Commun. 14:193-198. https://doi.org/10.1007/BF00347737.

Rasmussen, M. D., and T. C. Hemling. 2002. The influence of automatic teat spraying on teat condition. Pages $166-167$ in NMC Annual Meeting Proc., Orlando, FL., National Mastitis Council, Madison, WI.

Reyher, K. K., I. R. Dohoo, D. T. Scholl, and G. P. Keefe. 2012a. Evaluation of minor pathogen intramammary infection, susceptibility parameters, and somatic cell counts on the development of new intramammary infections with major mastitis pathogens. J. Dairy Sci. 95:3766-3780. https://doi.org/10.3168/jds.2011-5148.

Reyher, K. K., S. Dufour, H. W. Barkema, L. Des Coteaux, T. J. Devries, I. R. Dohoo, G. P. Keefe, J. P. Roy, and D. T. Scholl. 2011. The National Cohort of Dairy Farms - A data collection platform for mastitis research in Canada. J. Dairy Sci. 94:16161626. https://doi.org/10.3168/jds.2010-3180.

Reyher, K. K. K., D. Haine, I. R. R. Dohoo, and C. W. W. Revie. 2012b. Examining the effect of intramammary infections with minor mastitis pathogens on the acquisition of new intramammary infections with major mastitis pathogens - A systematic review and meta-analysis. J. Dairy Sci. 95:6483-6502. https://doi.org/10 $.3168 /$ jds.2012-5594.

Sampimon, O. C., H. W. Barkema, I. M. G. A. Berends, J. Sol, and T. J. G. M. Lam. 2009. Prevalence and herd-level risk factors for intramammary infection with coagulase-negative staphylococci in Dutch dairy herds. Vet. Microbiol. 134:37-44. https://doi.org/10 .1016/j.vetmic.2008.09.010.

Schukken, Y. H., R. N. Gonzalez, L. L. Tikofsky, H. F. Schulte, C. G. Santisteban, F. L. Welcome, G. J. Bennett, M. J. Zurakowski, and R. N. Zadoks. 2009. CNS mastitis: Nothing to worry about? Vet. Microbiol. 134:9-14. https://doi.org/10.1016/j.vetmic.2008 .09.014.

Stamer, E., W. Brade, and G. Thaller. 2011. Modelling and estimation of genetic parameters for milk urea content in first and second parity Holstein cows. Zuchtungskunde 83:104-117.

Stevens, M., S. Piepers, K. Supré, J. Dewulf, and S. De Vliegher. 2016. Quantification of antimicrobial consumption in adult cattle on dairy herds in Flanders, Belgium, and associations with udder health, milk quality, and production performance. J. Dairy Sci. 99:2118-2130. https://doi.org/10.3168/jds.2015-10199.

Supré, K., S. De Vliegher, O. C. C. Sampimon, R. N. N. Zadoks, M. Vaneechoutte, M. Baele, E. De Graef, S. Piepers, and F. Haesebrouck. 2009. Technical note: Use of transfer RNA-intergenic spacer PCR combined with capillary electrophoresis to identify coagulase-negative Staphylococcus species originating from bovine milk and teat apices. J. Dairy Sci. 92:3204-3210. https://doi.org/ $10.3168 /$ jds.2008-1923.

Supré, K., F. Haesebrouck, R. N. N. Zadoks, M. Vaneechoutte, S. Piepers, and S. De Vliegher. 2011. Some coagulase-negative Staphylococcus species affect udder health more than others. J. Dairy Sci. 94:2329-2340. https://doi.org/10.3168/jds.2010-3741. 
Taponen, S., J. Björkroth, and S. Pyörälä. 2008. Coagulase-negative staphylococci isolated from bovine extramammary sites and intramammary infections in a single dairy herd. J. Dairy Res. 75:422429. https://doi.org/10.1017/S0022029908003312.

Taponen, S., J. Koort, J. Björkroth, H. Saloniemi, and S. Pyörälä. 2007. Bovine intramammary infections caused by coagulase-negative staphylococci may persist throughout lactation according to amplified fragment length polymorphism-based analysis. J. Dairy Sci. 90:3301-3307. https://doi.org/10.3168/jds.2006-860.

Taponen, S., H. Simojoki, M. Haveri, H. D. Larsen, and S. Pyörälä. 2006. Clinical characteristics and persistence of bovine mastitis caused by different species of coagulase-negative staphylococci identified with API or AFLP. Vet. Microbiol. 115:199-207. https: /doi.org/10.1016/j.vetmic.2006.02.001.

Tenhagen, B.-A., G. Köster, J. Wallmann, and W. Heuwieser. 2006. Prevalence of mastitis pathogens and their resistance against antimicrobial agents in dairy cows in Brandenburg, Germany. J. Dairy Sci. 89:2542-2551. https://doi.org/10.3168/jds.S0022 -0302(06)72330-X.

Thorberg, B.-M., M.-L. Danielsson-Tham, U. Emanuelson, and K. Persson Waller. 2009. Bovine subclinical mastitis caused by different types of coagulase-negative staphylococci. J. Dairy Sci. 92:4962-4970. https://doi.org/10.3168/jds.2009-2184.

Timms, L. L., and L. H. Schultz. 1987. Dynamics and significance of coagulase-negative staphylococcal intramammary infections. J. Dairy Sci. 70:2648-2657. https://doi.org/10.3168/jds.S0022 -0302(87)80335-1.

Todhunter, D. A., L. L. Cantwell, K. L. Smith, K. H. Hoblet, and J. S. Hogan. 1993. Characteristics of coagulase-negative staphylococci isolated from bovine intramammary infections. Vet. Microbiol. 34:373-380. https://doi.org/10.1016/0378-1135(93)90062-C.

Tomazi, T., J. L. Goncalves, J. R. Barreiro, M. A. Arcari, and M. V. dos Santos. 2015. Bovine subclinical intramammary infection caused by coagulase-negative staphylococci increases somatic cell count but has no effect on milk yield or composition. J. Dairy Sci. 98:3071-3078. https://doi.org/10.3168/jds.2014-8466.

Valckenier, D., S. Piepers, A. De Visscher, R. M. Bruckmaier, and S. De Vliegher. 2019. Effect of intramammary infection with non- aureus staphylococci in early lactation in dairy heifers on quarter somatic cell count and quarter milk yield during the first 4 months of lactation. J. Dairy Sci. 102:6442-6453. https://doi.org/10.3168/ jds.2018-15913.

Valckenier, D., S. Piepers, A. De Visscher, and S. De Vliegher. 2020. The effect of intramammary infection in early lactation with nonaureus staphylococci in general and Staphylococcus chromogenes specifically on quarter milk somatic cell count and quarter milk yield. J. Dairy Sci. 103:768-782. https://doi.org/10.3168/jds.2019 $-16818$.

van der Poel, W. H., M. C. Mourits, M. Nielen, K. Frankena, J. T. Van Oirschot, and Y. H. Schukken. 1995. Bovine respiratory syncytial virus reinfections and decreased milk yield in dairy cattle. Vet. Q. 17:77-81. https://doi.org/10.1080/01652176.1995.9694537.

Vanderhaeghen, W., S. Piepers, F. Leroy, E. Van Coillie, F. Haesebrouck, and S. De Vliegher. 2015. Identification, typing, ecology and epidemiology of coagulase negative staphylococci associated with ruminants. Vet. J. 203:44-51. https://doi.org/10.1016/j.tvjl .2014.11.001.

Wilson, D. J., R. N. Gonzalez, and H. H. Das. 1997. Bovine mastitis pathogens in New York and Pennsylvania: Prevalence and effects on somatic cell count and milk production. J. Dairy Sci. 80:25922598. https://doi.org/10.3168/jds.S0022-0302(97)76215-5.

Wu, X.-L., B. Heringstad, Y.-M. Chang, G. de los Campos, and D. Gianola. 2007. Inferring relationships between somatic cell score and milk yield using simultaneous and recursive models. J. Dairy Sci. 90:3508-3521. https://doi.org/10.3168/jds.2006-762.

\section{ORCIDS}

D. Valckenier @ https://orcid.org/0000-0002-7535-2778

S. Piepers (ํ) https://orcid.org/0000-0003-4753-9321

Y. H. Schukken ® https://orcid.org/0000-0002-8250-4194

F. Boyen (ㄴ) https://orcid.org/0000-0002-4777-6880

F. Haesebrouck (1) https://orcid.org/0000-0002-1709-933X

S. De Vliegher $\odot$ https://orcid.org/0000-0001-6330-9062 